\title{
Interrelationships between Somatostatin sst2A Receptors and Somatostatin-Containing Axons in Rat Brain: Evidence for Regulation of Cell Surface Receptors by Endogenous Somatostatin
}

\author{
Pascal Dournaud, ${ }^{1}$ Hélène Boudin ${ }^{1}$, Agnes Schonbrunn, ${ }^{3}$ Gloria S. Tannenbaum, ${ }^{1,2}$ and Alain Beaudet ${ }^{1}$ \\ Departments of ${ }^{1}$ Neurology and Neurosurgery and ${ }^{2}$ Pediatrics, McGill University, Montreal, Quebec H3A 2B4, Canada \\ and ${ }^{3}$ Department of Integrative Biology and Pharmacology, University of Texas, Houston Medical School, \\ Houston, Texas 77225
}

\begin{abstract}
Using an antipeptide antibody, we reported previously on the distribution of the somatostatin Sst2A receptor subtype in rat brain. Depending on the region, immunolabeled receptors were either confined to neuronal perikarya and dendrites or distributed diffusely in tissue. To investigate the functional significance of these distribution patterns, we examined the regional and cellular relationships between somatostatin axons and sst2A receptors in the rat CNS, using double-labeling immunocytochemistry. Light and confocal microscopy revealed a significant correlation $(p<0.02)$ between the distribution of somatodendritic sst2A receptor immunoreactivity and that of somatostatin terminal fields, both quantitatively and qualitatively. Furthermore, in regions of somatodendritic labeling, a subpopulation of sst2A-immunoreactive cells was also immunopositive for somatostatin, suggesting that a subset of sst2A receptors consists of autoreceptors. By contrast, in regions displaying diffuse sst2A labeling only moderate to low densities of somatostatin terminals were observed, and no significant relationship was found between terminal density and receptor immunoreactivity.
\end{abstract}

At the electron microscopic level, areas expressing somatodendritic sst2A labeling were found by immunogold cytochemistry to display low proportions of membrane-associated, as compared with intracellular, receptors. Conversely, in regions displaying diffuse sst2A receptor labeling, receptors were predominantly associated with neuronal plasma membranes, a finding consistent with the high density of sst2 binding sites previously visualized in these areas by autoradiography. Double-labeling studies demonstrated that in the former but not in the latter regions, sst2A-immunoreactive somata and dendrites were heavily contacted by somatostatin axon terminals. Taken together, these results suggest that the low incidence of membrane-associated receptors observed in regions of somatodendritic sst2A labeling may be caused by downregulation of cell surface receptors by endogenous somatostatin, possibly through ligand-induced receptor internalization.

Key words: somatostatin; receptors; immunohistochemistry; electron microscopy; internalization; receptor-transmitter mismatch
Somatostatin (SRIF) is a tetradecapeptide originally isolated from hypothalamus (Brazeau et al., 1973) and subsequently found to be distributed throughout the neuraxis as well as in various peripheral organs (Reichlin, 1983). Within the brain, SRIF acts as a neuromodulator with widespread physiological effects on neuroendocrine, cognitive, and behavioral functions (Tannenbaum, 1985; Epelbaum et al., 1994). Accordingly, deficits in SRIF and SRIF receptors have been documented in a number of neurological disorders, including epilepsy (Schwarzer et al., 1996) and Alzheimer's disease (Epelbaum et al., 1994). Mammalian SRIF biosynthesis involves the post-translational proteolytic processing of a single pro-SRIF precursor into the bioactive peptides

Received Aug. 8, 1997; revised Oct. 3, 1997; accepted Nov. 14, 1997.

This work was supported by grants from the Fonds de la Recherche en Santé du Québec and the Medical Research Council of Canada to G.S.T. and A.B., and from the National Institutes of Health to A.S. G.S.T. is the recipient of a "Chercheur de carrière" award from the Fonds de la Recherche en Santé du Québec. We thank Mariette Houle and Christian Charbonneau for expert technical assistance. We are also grateful to Dr. V. M. Pickel for her tutoring of the immunogold ultrastructural localization technique.

P.D. and H.B. contributed equally to this work.

Correspondence should be addressed to Dr. Alain Beaudet, Montreal Neurological Institute, McGill University, 3801 University Street, Montreal, Quebec H3A 2B4, Canada.

Dr. Dournaud's present address: Institut National de la Santé et de la Recherche Médicale, U-159, Centre Paul Broca, 2 Ter rue d'Alésia, 75014 Paris, France. Copyright (C) 1998 Society for Neuroscience $0270-6474 / 98 / 181056-16 \$ 05.00 / 0$
SRIF-14 and SRIF-28, the latter being a 14-residue $\mathrm{NH}_{2}$ terminally extended form of the tetradecapeptide (Pradayrol et al., 1980; Schally et al., 1980). Immunohistochemical studies have demonstrated the presence of multiple populations of SRIFcontaining nerve cells bodies in mammalian brain, which give rise to extensive networks of SRIF-immunoreactive fibers and axon terminals (Johannson et al., 1984). Except for a single SRIF-28selective neuronal system arising from the nucleus of the solitary tract and projecting to the magnocellular hypothalamic nuclei (Sawchenko et al., 1988), SRIF-immunoreactive neurons contain both SRIF-14 and SRIF-28, in a proportion of $\sim 3$ to 1 .

Five types of SRIF receptors, designated sst1-sst5 (Bruno et al., 1992; O’Carroll et al., 1992; Yamada et al., 1992; Yasuda et al., 1992), mediate the diverse functional effects of SRIF in the CNS. Experiments on transfected cells have shown that the proteins encoded by the cloned SRIF receptor genes display high affinity for both SRIF-14 and SRIF-28 (Patel et al., 1995; Reisine and Bell, 1995; Schindler et al., 1996). They also bind with high-affinity cortistatin (Fukusumi et al., 1997), a neuropeptide with considerable homology with SRIF but derived from a different gene product (De Lecea et al., 1996). All five SRIF receptors are linked to guanine nucleotide binding proteins (Gproteins) that mediate the responses of diverse cellular effectors (Gu et al., 1995; Hoyer et al., 1995; Gu and Schonbrunn, 1997). In human and rodent tissues, the sst 2 receptor was shown to exist in 
two isoforms, sst2A and sst2B, generated through alternative splicing of the sst2 mRNA at the $3^{\prime}$ end of the coding segment (Vanetti et al., 1992). These two variants, which differ only in length and in their amino acid sequence at the $\mathrm{C}$ terminus, exhibit indistinguishable binding properties but vary in G-protein coupling and desensitization (Vanetti et al., 1993).

Autoradiographic receptor binding studies have shown a widespread but selective distribution of SRIF binding sites in mammalian brain (Martin et al., 1991; Krantic et al., 1992; Moyse et al., 1992; Schoeffter et al., 1995; Holloway et al., 1996). Recently, the development of antisera against selective peptide sequences of the sst2A receptor has allowed us (Dournaud et al., 1996) and others (Schindler et al., 1997) to document the distribution of this receptor protein in rat brain by immunocytochemistry. This distribution conformed for the most part to that of SRIF binding sites detected using either nonselective (for review, see Krantic et al., 1992) or sst2-preferring (Reubi and Maurer, 1985; Krantic et al., 1989, 1990; Martin et al., 1991; Schoeffter et al., 1995; Holloway et al., 1996) ligands, suggesting that other SRIF receptor subtypes are expressed within the same regions (Dournaud et al., 1996; Schindler et al., 1997). However, there were marked regional differences in the light microscopic distribution of sst2A protein: in some areas, immunolabeled receptors were selectively associated with neuronal perikarya and dendrites, whereas in others they appeared diffusely distributed throughout the tissue (Dournaud et al., 1996). In the present study, we sought to investigate the functional significance of these differential labeling patterns by correlating the regional, cellular, and subcellular distribution of sst $2 \mathrm{~A}$ receptors with that of SRIF-containing axon terminals in rat brain using light, confocal, and electron microscopy.

\section{MATERIALS AND METHODS}

\section{Antibodies}

The R-88 rabbit polyclonal antibody, generated against a unique sequence located in the $\mathrm{C}$-terminal tail of the sst2A receptor, and the rat monoclonal antibody (mAb) 354 (Chemicon, Temecula, CA), raised against SRIF-14, were used as primary antibodies. Biochemical and immunohistochemical characterization of the respective antibodies have been reported elsewhere (Dun et al., 1994; Dournaud et al., 1996; Gu and Schonbrunn, 1997). We further characterized the mAb 354 antibody by ELISA and found it to cross-react with both SRIF-28 and cortistatin, as well as with SRIF-14, at the dilutions used in the present experiments.

\section{Light microscopy}

Single-labeling experiments. Adult male Sprague Dawley rats (150-200 gm body weight; $n=5)$ were anesthetized with Somnotol $(80 \mathrm{mg} / \mathrm{kg}$, i.p.) and perfused transaortically with $4 \%$ paraformaldehyde in $0.1 \mathrm{M}$ Trisbuffered saline (TBS). Brains were cryoprotected by overnight immersion in a $30 \%$ sucrose solution and frozen in liquid isopentane at $-45^{\circ} \mathrm{C}$. The brains were sectioned at a thickness of $30 \mu \mathrm{m}$ on a freezing microtome. Adjacent serial sections throughout the brain were processed for sst2A receptor and SRIF immunohistochemistry.

Sections were preincubated for $30 \mathrm{~min}$ in TBS containing 3\% normal goat serum (NGS) and incubated for $16 \mathrm{hr}$ at room temperature (RT) in 1:2000 rabbit anti-sst2A antibody or 1:100 rat anti-SRIF antibody dilutions containing $0.3 \%$ Triton $\mathrm{X}-100$. Sections were then rinsed in $0.1 \mathrm{~m}$ TBS and sequentially incubated for $45 \mathrm{~min}$ in biotinylated goat antirabbit IgG or biotinylated goat anti-rat IgG (Jackson ImmunoResearch, West Grove, PA) diluted 1:100 in 0.1 м TBS. They were then incubated for $45 \mathrm{~min}$ in avidin-biotin-peroxidase solution (ABC) (Vector Laboratories, Burlingame, $\mathrm{CA}$ ) and subsequently incubated for $10 \mathrm{~min}$ in a $0.01 \%$ biotinyl-tyramide solution (DuPont, Billerica, MA), activated with $0.01 \% \mathrm{H}_{2} \mathrm{O}_{2}$, and reincubated in the $\mathrm{ABC}$ solution. Visualization of the bound peroxidase was achieved by reaction in a solution of $0.1 \mathrm{M}$ Tris buffer containing $0.05 \%$ 3,3' diaminobenzidine (DAB), $0.04 \%$ nickel chloride, and $0.01 \% \mathrm{H}_{2} \mathrm{O}_{2}$. Sections were mounted on gelatin-coated slides, dehydrated in graded ethanols, delipidated in xylene, coverslipped with Permount, and examined with a Leitz Aristoplan microscope. Control experiments were performed by either omitting the primary antibody or by replacing it with serum preabsorbed with $10 \mu \mathrm{M}$ antigenic peptide (for sst2A) or SRIF-14 (for SRIF). Sst2A receptor labeling was first defined as being either somatodendritic (Table 1) or diffuse (Table 2). Labeling densities were then scored for each labeled region on a scale of + to +++++ according to both the number of labeled elements and the density of immunoreactive signal. Densities of SRIF-immunoreactive axon terminals detected in the same regions on adjacent sections were assessed according to the same scale. Distributions of sst2A receptors and SRIF axons were compared statistically using Spearman's correlation coefficient. Densities of sst2A immunolabeling were also correlated with those of SRIF binding sites documented previously by quantitative autoradiography using sst2-preferring ligands (Tables 1,2).

Double-labeling experiments. Serial frozen brain sections were prepared as above ( $n=5$ rats) and coincubated for $16 \mathrm{hr}$ at RT in a mixture of 1:2000 rabbit anti-sst2A antibody and 1:100 rat anti-SRIF antibody containing $0.3 \%$ Triton $\mathrm{X}-100$. Sections were rinsed in $0.1 \mathrm{M}$ TBS and sequentially incubated for $45 \mathrm{~min}$ in biotinylated goat-anti-rabbit $\mathrm{IgG}$ diluted 1:200 in 0.1 M TBS and in ABC solution for $45 \mathrm{~min}$. They were then incubated as above for $10 \mathrm{~min}$ in the biotinyl-tyramide solution and reincubated in ABC. After several washes, sections were coincubated for $1 \mathrm{hr}$ in a mixed solution of 1:2000 rhodamine (TRITC)-conjugated streptavidin (Jackson ImmunoResearch) and 1:100 fluorescein (FITC)conjugated goat anti-rat IgG (Jackson ImmunoResearch). They were then washed in TBS and mounted with Aquamount. The absence of cross-reactivity between the secondary antibodies was verified by omitting one of the primary antibodies during the overnight incubation.

Double-labeled sections were analyzed by confocal microscopy using a Leica laser scanning microscope (CLSM) equipped with a Leica Diaplan inverted microscope, an argon/krypton ion laser (488 nm), and a VME bus MC 68020/68881 computer system (Leica, Wetzlar, Germany). All imagegenerating and -processing operations were performed with the Leica CLSM software package. Images were acquired simultaneously for the two fluorophores (FITC and TRITC). For each image, 10 optical sections separated by $0.24 \mu \mathrm{m}$ steps were acquired, averaged over 32 scans per frame, and reconstructed. Micrographs were taken from the image monitor using a Focus ImageCorder (Focus Graphics, Foster City, CA).

\section{Electron microscopy}

For electron microscopic studies, rats were perfused transaortically with $30 \mathrm{ml}$ of heparin $(100 \mathrm{U} / \mathrm{ml}$ heparin in $0.9 \% \mathrm{NaCl})$, sequentially followed by a mixture of $50 \mathrm{ml}$ of $3.75 \%$ acrolein and $2 \%$ paraformaldehyde in 0.1 M phosphate buffer (PB), pH 7.4, and by $200 \mathrm{ml}$ of $2 \%$ paraformaldehyde in the same buffer. The brain was then removed and post-fixed for $30 \mathrm{~min}$ in the paraformaldehyde solution. Coronal sections (40- $\mu \mathrm{m}$-thick) were cut on a vibratome and collected in PB. Sections were then processed either for single sst $2 \mathrm{~A}$ immunogold labeling or for sst2A/SRIF combined immunogold/immunoperoxidase labeling, according to protocols established by Chan et al. (1990).

Single-labeling experiments. For single-labeling experiments $(n=4)$, tissue sections were incubated in a solution of $1 \%$ sodium borohydride in $\mathrm{PB}$ for $30 \mathrm{~min}$ to neutralize free aldehyde groups and rinsed copiously with PB. They were then cryoprotected for $30 \mathrm{~min}$ in a solution of $25 \%$ sucrose and $3 \%$ glycerol in $0.05 \mathrm{M} \mathrm{PB}$, frozen rapidly in isopentane at $-70^{\circ} \mathrm{C}$, transferred to liquid nitrogen, and thawed in $\mathrm{PB}$ at RT. Sections were incubated for $30 \mathrm{~min}$ in TBS containing 3\% NGS followed by $16 \mathrm{hr}$ at $4^{\circ} \mathrm{C}$ in rabbit sst2A antibody diluted $1: 350$ in TBS containing $0.5 \%$ NGS. They were then rinsed in $0.01 \mathrm{M}$ PBS (0.01 M PB, pH 7.4, containing $0.9 \% \mathrm{NaCl}$ ), incubated for $2 \mathrm{hr}$ in a 1:50 dilution of colloidal gold (1 nm)-conjugated goat anti-rabbit IgG (Amersham, Arlington Heights, IL) diluted in PBS containing $0.2 \%$ gelatin and $0.8 \%$ BSA, and fixed for $10 \mathrm{~min}$ in $2 \%$ glutaraldehyde in PBS. After several washes in 0.2 $\mathrm{M}$ citrate buffer, $\mathrm{pH} 7.4$, immunogold was silver-enhanced by incubation for $7 \mathrm{~min}$ in the silver solution of IntenSE M kit (Amersham). The reaction was stopped by washes in citrate buffer, and sections were prepared for electron microscopy as described below.

Double-labeling experiments. For double-labeling experiments $(n=4)$, vibratome-cut sections were incubated for $16 \mathrm{hr}$ at $4^{\circ} \mathrm{C}$ in a mixture of rabbit sst2A antibody (diluted 1:350) and rat SRIF antibody (diluted $1: 25$ ) in TBS containing $0.5 \%$ NGS. SRIF immunoreactivity was first revealed using the immunoperoxidase method. Briefly, sections were incubated sequentially for $30 \mathrm{~min}$ in biotinylated goat anti-rat IgG diluted 1:100 in $0.1 \mathrm{M}$ TBS and for $30 \mathrm{~min}$ in ABC solution. Visualization of the bound peroxidase was achieved by reaction in a solution of $0.1 \mathrm{M}$ Tris 


\begin{tabular}{|c|c|c|c|}
\hline Region & $\begin{array}{l}\text { sst2A receptor- } \\
\text { positive neurons } \\
\text { and dendrites }\end{array}$ & $\begin{array}{l}\text { SRIF-positive } \\
\text { fibers and } \\
\text { axon terminals }\end{array}$ & $\begin{array}{l}\text { Preferential } \\
\text { sst } 2 \text { binding }\end{array}$ \\
\hline Bed nucleus stria terminalis & +++++ & +++++ & ++ \\
\hline \multicolumn{4}{|l|}{ Olfactory tubercle } \\
\hline layer II & ++++ & ++++ & + \\
\hline Central amygdaloid nucleus & ++++ & ++++ & ++ \\
\hline \multicolumn{4}{|c|}{ CA1-CA2 fields of the hippocampus } \\
\hline Stratum pyramidale & +++++ & + & + \\
\hline Nucleus accumbens & ++++ & ++++ & ++ \\
\hline \multicolumn{4}{|l|}{ Cerebral cortex } \\
\hline layer II & +++ & ++ & ++ \\
\hline Medial habenula & +++ & + & ++++ \\
\hline \multicolumn{4}{|l|}{ Caudoputamen } \\
\hline caudal & +++ & +++ & + \\
\hline Substriatal area & +++ & +++ & ++ \\
\hline Medial amygdaloid nucleus & +++ & +++ & ++ \\
\hline Cortical amygdaloid nucleus & +++ & +++ & ++ \\
\hline Locus coeruleus & +++ & + & +++ \\
\hline Spinal trigeminal tract & +++ & +++ & ++++ \\
\hline Lateral reticular nucleus & +++ & +++ & ++ \\
\hline \multicolumn{4}{|l|}{ Caudoputamen } \\
\hline medial & ++ & ++ & + \\
\hline Dorsolateral septum & ++ & ++ & ++++ \\
\hline Central gray & ++ & ++ & +++ \\
\hline \multicolumn{4}{|l|}{ Cerebral cortex } \\
\hline layers V-VI & + & + & ++++ \\
\hline Diagonal band of Broca & + & + & + \\
\hline Hypothalamus & + & +++++ & ++ \\
\hline Superior colliculus & + & + & +++ \\
\hline Nucleus tractus solitarius & + & ++ & +++ \\
\hline
\end{tabular}

${ }^{a}$ Relative values. + , Very low signal; ++ , low signal; +++ , moderate signal; ++++ , high signal; +++++ , very high signal

${ }^{b}$ Based on literature data on the distribution and densities of radioautographic labeling obtained using sst2-preferring ligands (Reubi and Maurer, 1985; Krantic et al., 1989, 1990; Martin et al., 1991; Schoeffter et al., 1995; Holloway et al., 1996).

buffer containing $0.05 \% \mathrm{DAB}$ and $0.01 \% \mathrm{H}_{2} \mathrm{O}_{2}$. After several washes in PBS, sst2A immunolabeling was visualized using the immunogold method as described above. The absence of cross-reactivity between the secondary antibodies was verified by omitting one of the primary antibodies during the overnight incubation.

Electron microscopy. Both single- and double-labeled sections were post-fixed with $2 \%$ osmium tetroxide in $0.1 \mathrm{M} \mathrm{PB}$ for $40 \mathrm{~min}$, dehydrated in graded ethanols and propylene oxide, and flat-embedded in Epon 812 between two sheets of acetate. Ultrathin sections $(80 \mathrm{~nm})$ were collected from the bed nucleus of the stria terminalis, central and basolateral amygdaloid nucleus, and claustrum. The ultrathin sections were then counterstained with lead citrate and uranyl acetate and examined with a JEOL 100CX electron microscope.

Quantitative analyses. The subcellular distribution of silver-enhanced gold particles was analyzed in sections from two different animals. For each experiment, three blocks were cut and grids containing surface tissue sections were systematically scanned with the electron microscope. We assumed that each silver-enhanced gold particle that was detected corresponded to a specific labeling site, because control experiments performed by omitting the primary antibody showed only exceedingly low background levels. Each labeled element (classified as such if it contained one silver grain or more) was photographed at an original magnification of $10,000-14,000 \times$ to reach a total number of 400 grains per experiment. Gold particles were then classified according to the type of element with which they were associated (dendritic, somatic, or axonal) and whether they were associated with the cytoplasm or the plasma membrane. A gold particle was considered to be associated with the plasma membrane when it contacted or overlaid it. Particles that did not contact the plasma membrane, even if close, were classified as intracel- lular. Cross-sectional surfaces of immunoreactive elements were also measured using computer-assisted morphometry to determine whether the proportion of intracellular versus membrane-associated particles was dependent on sampling.

To assess the proportion of SRIF-immunoreactive terminals in contact with sst2A elements, immunoperoxidase-labeled axonal profiles encountered in double-labeled sections from the bed nucleus of the stria terminalis $(n=168)$ and the central nucleus of the amygdala $(n=69)$ from two animals were analyzed according to size, presence or not of a contact with a sst2A-immunolabeled element, and length of contact and presence of a synaptic specialization and immunogold particles at the site of contact. All measurements (mean terminal diameter; length of appositions) were performed using a computer-assisted image analysis system (Historag; Biocom, Les Ulis, France).

\section{RESULTS}

\section{Comparative distribution of sst2A receptors and SRIF axons at the light microscopic level}

Light microscopic examination of sections processed for sst2A receptor immunohistochemistry revealed the same regional distributional pattern of immunoreactivity as reported previously (Dournaud et al., 1996; Schindler et al., 1997). This immunolabeling was no longer observed when sections were incubated with immune serum preadsorbed with an excess of antigenic peptide. The distribution of SRIF immunoreactivity, as observed in sections adjacent to the ones processed for the sst $2 \mathrm{~A}$ receptor, was 
Table 2. Comparison of diffuse sst2A receptor labeling with the density of SRIF immunoreactive fibers and axon terminals and autoradiographic sst2 receptor labeling ${ }^{a}$

\begin{tabular}{|c|c|c|c|}
\hline Region & $\begin{array}{l}\text { Diffuse } \\
\text { sst } 2 \text { A receptor } \\
\text { labeling }\end{array}$ & $\begin{array}{l}\text { SRIF-positive } \\
\text { fibers and } \\
\text { axon terminals }\end{array}$ & $\begin{array}{l}\text { Preferential sst } 2 \\
\text { binding }^{b}\end{array}$ \\
\hline Endopiriform nucleus & +++++ & ++ & +++++ \\
\hline Claustrum & +++++ & ++ & +++++ \\
\hline \multicolumn{4}{|l|}{ Hippocampal formation } \\
\hline Lacunosum moleculare (CA1-CA2) & +++++ & + & +++++ \\
\hline Subiculum & +++++ & + & +++++ \\
\hline Basolateral amygdaloid nucleus & +++++ & + & +++++ \\
\hline \multicolumn{4}{|l|}{ Cerebral cortex } \\
\hline Layers V-VI & ++++ & + & ++++ \\
\hline Anterior olfactory nucleus & +++ & ++ & +++ \\
\hline Central gray & +++ & ++ & +++ \\
\hline Lateral olfactory tract nucleus & +++ & + & ++++ \\
\hline Medial habenula & +++ & + & ++++ \\
\hline Locus coeruleus & +++ & + & +++ \\
\hline \multicolumn{4}{|l|}{ Hippocampal formation } \\
\hline Dentate gyrus & ++ & + & +++ \\
\hline Substantia innominata & ++ & ++ & + \\
\hline Nucleus tractus solitarius & ++ & ++ & +++ \\
\hline Hypothalamus & + & +++++ & ++ \\
\hline Paraventricular thalamus & + & ++ & ++ \\
\hline Zona incerta & + & ++ & ++ \\
\hline \multicolumn{4}{|l|}{ Substantia nigra } \\
\hline Pars compacta & + & + & ++ \\
\hline \multicolumn{4}{|l|}{ Hippocampal formation } \\
\hline Hilus & + & + & + \\
\hline
\end{tabular}

$\overline{{ }^{a} \text { Relative values. }+ \text {, Very low signal; }++ \text {, low signal; }+++ \text {, moderate signal; }++++ \text {, high signal; }+++++ \text {, very high signal. }}$ ${ }^{b}$ Based on literature data on the distribution and densities of radioautographic labeling obtained using sst2-preferring ligands (Reubi and Maurer, 1985; Krantic et al., 1989, 1990; Martin et al., 1991; Schoeffter et al., 1995; Holloway et al., 1996).

also similar to that published earlier (Johannson et al., 1984). Here again, the labeling was completely abolished when the antiserum was preincubated with $10 \mu \mathrm{M}$ SRIF-14.

At higher magnification of sst2A-immunolabeled sections, the immunostaining was selectively associated with neuronal perikarya and proximal dendrites in some regions (Table 1) but diffusely distributed throughout tissue in others (Table 2). By contrast, in sections immunostained for SRIF, the immunostaining was either present in perikarya and dendrites (with a greater staining of distal dendrites than observed with the sst2A antibody) or in small beaded fibers and punctate axon terminals.

\section{SRIF innervation of regions expressing somatodendritic sst $2 A$ receptors}

The highest densities of neuronal cell bodies and proximal dendrites expressing sst $2 \mathrm{~A}$ receptors were found in the bed nucleus of the stria terminalis, the olfactory tubercle, the central amygdaloid nucleus, the pyramidal cell layer of the CA1-CA2 fields of the hippocampus, and the nucleus accumbens (Table 1). Four of these five regions also exhibited among the highest densities of SRIFimmunostained terminals in the brain (Table 1). Furthermore, within each of these regions, there was a striking overlap between the distribution of SRIF terminal fields and that of sst2A-positive elements. Thus, in the bed nucleus of the stria terminalis, both SRIF-immunoreactive axon terminals and sst $2 \mathrm{~A}$-immunoreactive neurons were restricted to the lateral part of the nucleus (Fig. $\left.1 a, a^{\prime}\right)$. In the olfactory tubercle, sst2A-immunoreactive nerve cell bodies were densely distributed throughout layer II and extended into the anterior part of the medial forebrain bundle. Similarly, SRIF-immunoreactive axon terminals were most prominent within layer II and in the medial forebrain bundle area (Fig. $\left.1 b, b^{\prime}\right)$. Furthermore, sst $2 \mathrm{~A}$ receptor-expressing neurons and SRIF-immunoreactive fibers were both more numerous in the medial than in the lateral aspect of the tubercle. In the central nucleus of the amygdala, high numbers of sst2A-immunoreactive neurons were matched with high densities of SRIF axon terminals in both lateral and medial aspects of the nucleus (Fig. 2a,b). By contrast, the neighboring medial and cortical amygdaloid nuclei expressed only medium densities of both sst2A-immunoreactive perikarya and SRIF fibers (Table 1). The hippocampal formation was the only structure of the limbic system in which there was a high density of sst2A-expressing neurons in the face of a sparse SRIF innervation. Although pyramidal cells and their basal and apical dendrites were strongly immunoreactive for the sst2A receptor throughout the CA1-CA2 fields, only a few SRIFimmunoreactive fibers were visible at that level, meandering between pyramidal cells and in the outer part of the stratum oriens.

Medium densities of sst2A-immunoreactive neurons and dendrites were encountered in layer II of the cerebral cortex, the medial habenula, the caudal caudoputamen, the medial and cortical amygdaloid nucleus, the locus coeruleus, the spinal trigeminal tract, and the lateral reticular nucleus. Except for the medial habenula (Fig. 3a,b) and the locus coeruleus, in which the SRIF innervation was very sparse, all of these regions also showed 

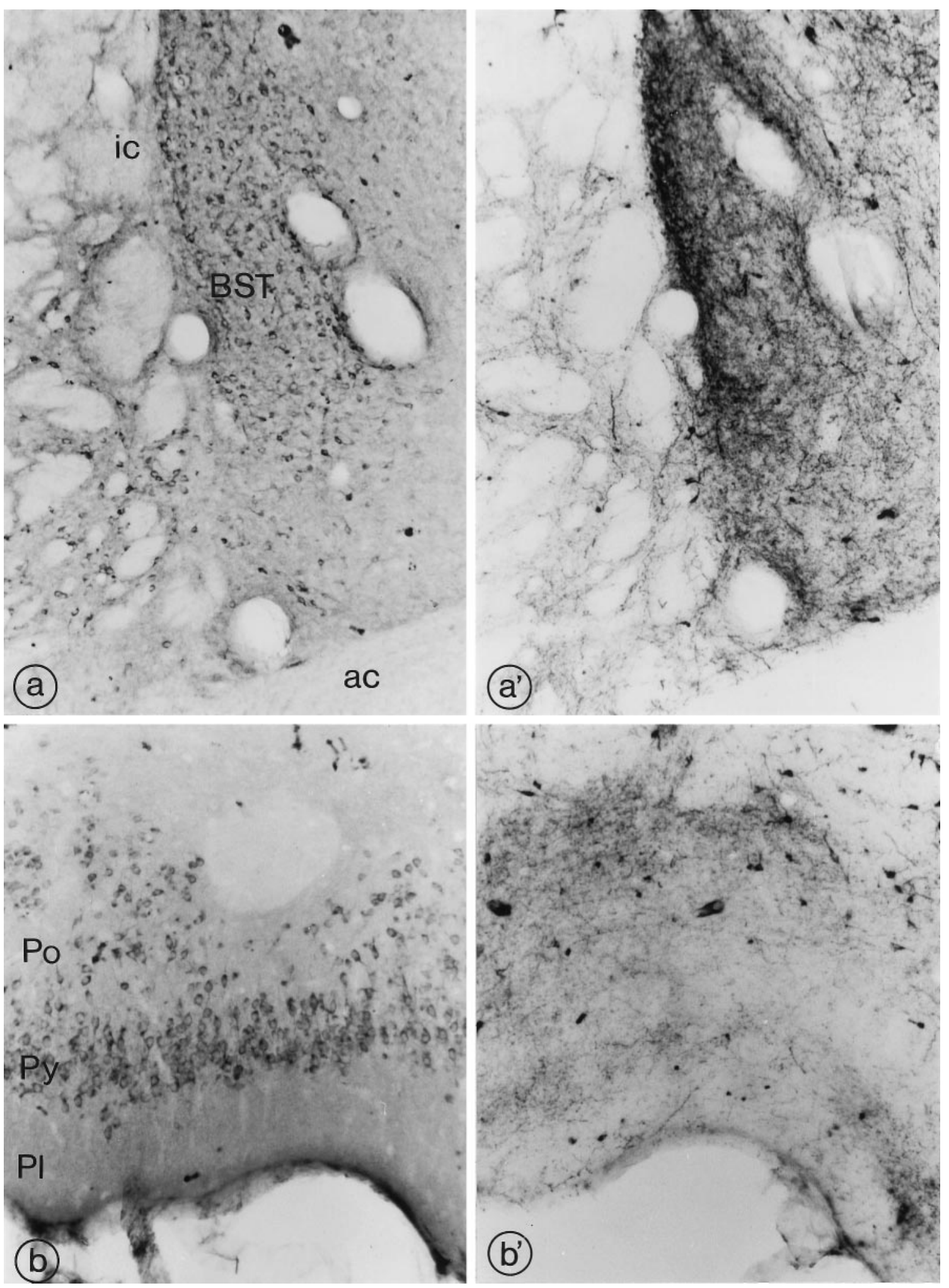

Figure 1. Distribution of sst2A receptor $(a, b)$ and SRIF immunoreactivity $\left(a^{\prime}, b^{\prime}\right)$ in the bed nucleus of the stria terminalis $\left(B S T\right.$; $\left.a, a^{\prime}\right)$ and the olfactory tubercle $\left(b, b^{\prime}\right)$. In both regions, strong sst2A immunoreactivity is apparent in nerve cell bodies and proximal dendrites. Note the close correspondence between patterns of SRIF terminal labeling and sst2A immunoreactivity in the mediolateral subdivision of the BST $\left(a, a^{\prime}\right)$ and pyramidal cell layer $(P y)$ of the olfactory tubercle $\left(b, b^{\prime}\right)$. $i c$, Internal capsule; $a c$, anterior commissure; $P o$, polymorphic cell layer; $P l$, plexiform layer. $a$, $a^{\prime}, 125 \times$ magnification; $b, b^{\prime}, 250 \times$ magnification. 


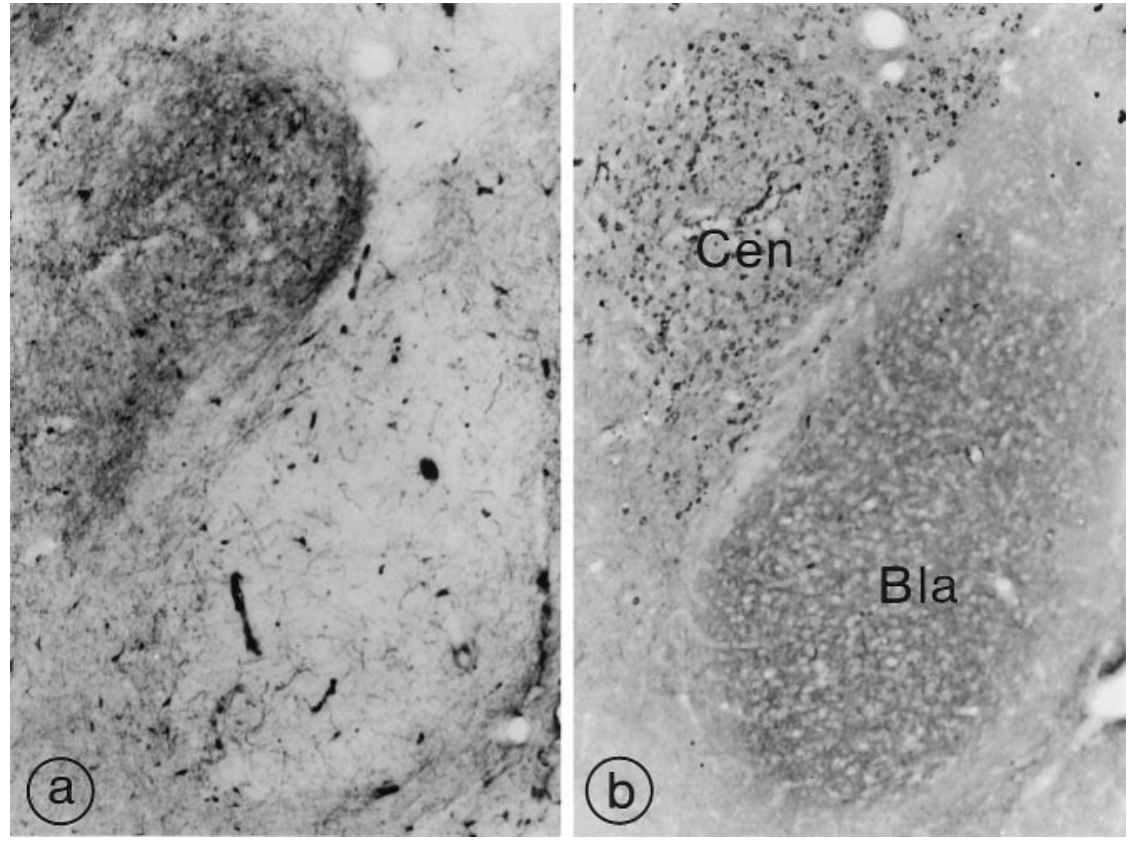

Figure 2. Comparative distribution of SRIF immunoreactivity $(a)$ and sst2A immunoreactivity $(b)$ in the central (Cen) and basolateral (Bla) nuclei of the amygdala. A prof use SRIF innervation $(a)$ as well as a high density of sst2A-expressing neurons are evident in the Cen. By contrast, only sparse SRIF fibers $(a)$ and diffuse sst2A labeling $(b)$ are visible in the Bla. Magnification, $80 \times$. medium densities of immunoreactive SRIF axon terminals (Table 1). Within each individual region, there was again a close topographic overlap between the two markers. This was best exemplified in the parietal cortex and rostral neostriatum. In the former, both SRIF-immunoreactive terminals and sst2A-immunoreactive nerve cell bodies and processes were more prominent in layers I and II than in deeper layers (Fig. 4a, $a^{\prime}$ ). In the latter, SRIFimmunoreactive axons and sst2A-immunoreactive aspiny neurons were both confined, rostrally, to the ventromedial part of the neostriatum between the myelinated fascicles of the internal capsule and along the edge of the globus pallidus (Fig. $4 b, b^{\prime}$ ). More caudally, they were found throughout the entire nucleus, again according to the same pattern of distribution and relative density.

Only low densities of sst2A-expressing neurons were detected in the diagonal band of Broca, the hypothalamus, the superior colliculus, and the nucleus tractus solitarius. Accordingly, only sparse SRIF-immunoreactive fibers were detected in these regions, with the exception of the hypothalamus, in which extensive somatostatin-fiber networks were apparent.

Overall, there was a highly significant correlation between the distribution of somatodendritic sst2A receptors and SRIF axon terminals $(p<0.02)$. By contrast, there was no significant correlation $(p<0.3)$ between the density of sst2A receptor-positive neurons/dendrites and that of SRIF binding sites documented previously by quantitative autoradiography using sst2-preferring ligands (Table 1).

\section{SRIF innervation of regions displaying diffuse sst $2 A$ immunolabeling}

By contrast with the high density of SRIF innervation found in regions expressing sst2A-immunoreactive perikarya and dendrites, only moderate to low densities of SRIF fibers and varicosities were seen in regions displaying diffuse sst2A labeling (Table 2). Thus, the endopiriform nucleus, the claustrum, the stratum lacunosum moleculare of the CA1 and CA2 fields of the hippocampus, the subiculum, the basolateral amygdaloid nucleus (Fig. 2a,b), and layers V-VI of cerebral cortex all displayed high densities of diffuse sst2A labeling but only few SRIF-positive fibers. Furthermore, there was no obvious relationship between the patterning of SRIF- and sst2A-immunoreactive structures in any of these areas.

The SRIF innervation was equally sparse in regions exhibiting only moderate intensity of sst2A diffuse labeling, such as the anterior olfactory nucleus, the central gray, the lateral olfactory tract nucleus, the dentate gyrus, the substantia innominata, and the nucleus tractus solitarius (Table 2).

In the hypothalamus, the paraventricular thalamus, the zona incerta, the substantia nigra pars compacta, and the hilus of the hippocampus, sst2A labeling was very low. Except for the hypothalamus, these regions also exhibited very low SRIF innervation, as illustrated in Figure 3 for the paraventricular nucleus of the thalamus. Overall, no significant relationship was found between diff use sst2A receptor labeling and the density of SRIFimmunoreactive fibers/axon terminals $(p=0.69)$. By contrast, there was a highly significant correlation $(p<0.0001)$ between the density of sst $2 \mathrm{~A}$ immunolabeling and that of SRIF binding sites documented previously by quantitative autoradiography using sst2-preferring ligands (Table 2).

\section{Colocalization of somatodendritic sst2A receptors and SRIF axon terminals at the confocal microscopic level}

To further investigate the relationships between SRIF axons and sst2A-expressing elements in areas in which the two showed a high degree of correspondence (i.e., areas of somatodendritic sst2A receptor localization), the two antigens were immunolabeled in the same sections and examined by confocal microscopy.

In these double-stained preparations, both TRITC-labeled sst2A receptor and FITC-labeled SRIF immunostaining showed distributional patterns and relative densities comparable to those found with the peroxidase procedure in adjacent sections. When R2-88 or mAb 354 antibodies were omitted during the doublelabeling procedure, respective TRITC- or FITC-fluorescence labeling was no longer observed in any of the sections examined, providing evidence that no cross-species reaction of secondary antisera had occurred.

Typically, somatodendritic sst2A labeling pervaded the cyto- 
Figure 3. Comparative distributions of SRIF immunoreactivity $(a)$ and sst2A immunoreactivity $(b)$ in the habenula and paraventricular nucleus of the thalamus. In the lateral habenula, a dense network of SRIF-immunoreactive axons is evident in both medial $(\mathrm{lhm})$ and lateral $(\mathrm{lhl})$ aspects of the nucleus $(a)$ in the absence of any obvious sst2A immunoreactivity $(b)$. By contrast, in the medial habenula, high densities of sst2A-immunoreactive processes $(b)$ are detected in the face of a sparse SRIF innervation. The paraventricular thalamic nucleus $(p v)$ displays low densities of either marker. Magnification, $80 \times$.

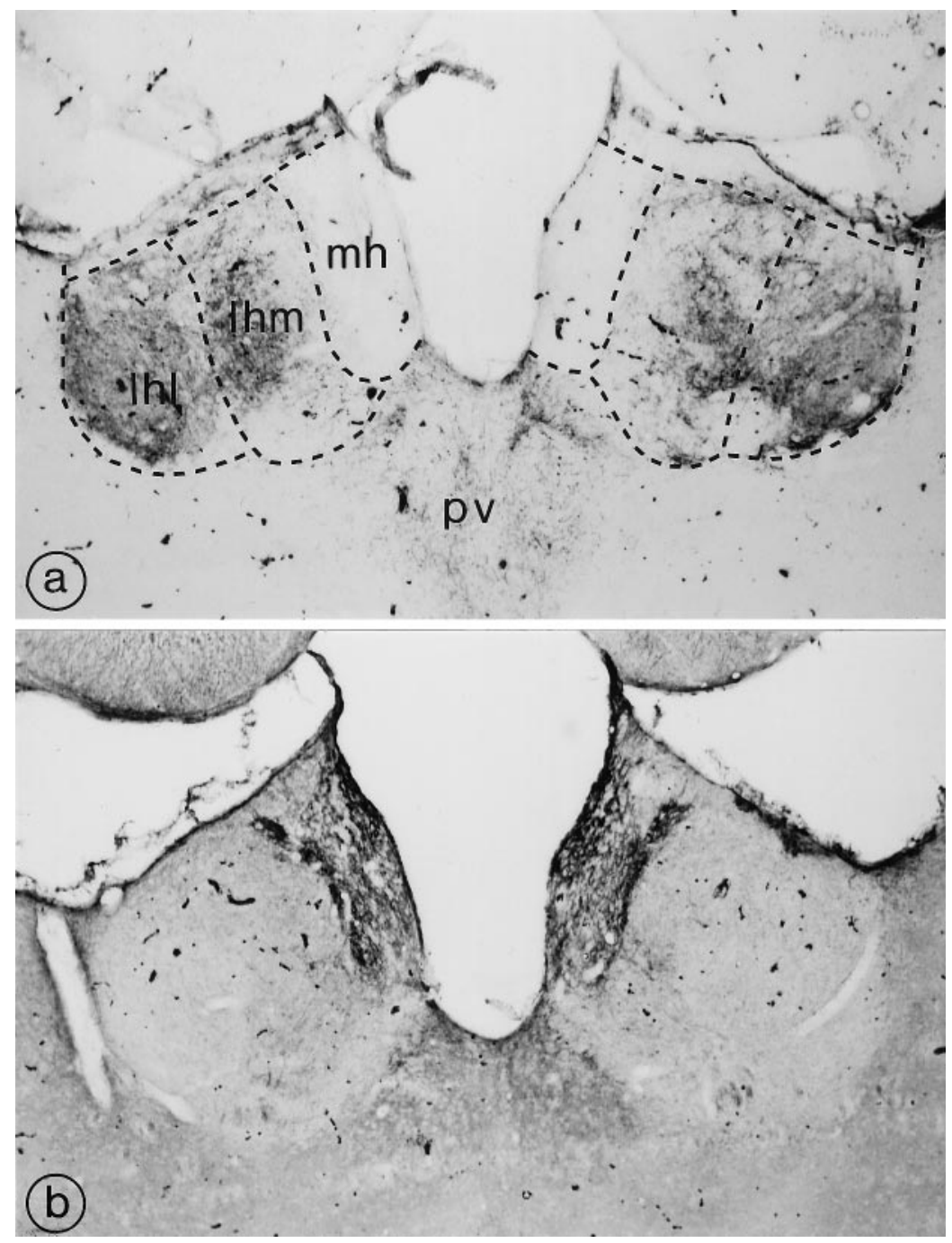

plasm of the perikarya, sparing the nucleus, and was confined mainly to proximal portions of primary dendrites (Fig. 5a,b,d,f). In some regions, however, the labeling was also evident within extensive dendritic arbors such as in the spinal trigeminal tract and lateral reticular nucleus (Fig. $5 c, e$ ). There was no preferential accumulation of sst $2 \mathrm{~A}$ immunoreactivity at the outskirts of the cells to suggest a preferential association with the plasma membrane.

In all of these regions, immunoreactive SRIF fibers overlapped heavily with sst2A receptor-expressing neurons (Fig. 5). Even in regions displaying moderate densities of both sst $2 \mathrm{~A}$ receptorexpressing neurons and SRIF innervation, extensive intermesh was evident between the two markers (Fig. $5 f$ ). In most instances, sst2A-immunoreactive perikarya and dendrites were embedded in a field of SRIF-immunoreactive axons. In many cases, however, individual SRIF varicose fibers or axon terminals were seen to appose sst2A-immunoreactive elements (Fig. 5a,b,c,e).

In several brain areas, SRIF nerve cell bodies were also apparent in regions expressing sst $2 \mathrm{~A}$ receptor immunoreactivity. There was no obvious correlation between the number and distribution of SRIF- and sst2A-immunoreactive cells. With conventional epifluorescence and confocal microscopy, however, it was apparent that in the central amygdaloid nucleus (Fig. 6a, $a^{\prime}$ ), the bed nucleus of the stria terminalis (Fig. $6 b, b^{\prime}$ ), the premammillary nucleus, and the lateral reticular nucleus (Fig. $6 c, c^{\prime}$ ), a subpopulation of cells immunoreactive for sst $2 \mathrm{~A}$ receptor was also immunopositive for SRIF. In other structures, even when both sst2Aand SRIF-expressing neurons were present, such as in cerebral cortex, neostriatum, or hypothalamus, no cellular colocalization of the two antigens was apparent. Because this study was conducted in noncolchicine-treated animals to optimize visualization of SRIF terminal fields, the number of SRIF-immunoreactive neurons, and thereby the occurrence frequency of double-labeled cells, is likely to have been underestimated. Thus we did not attempt to quantify neurons expressing both SRIF and sst2A receptors in any of the above brain regions.

\section{Electron microscopy}

The ultrastructural distribution of sst $2 \mathrm{~A}$ receptors was examined using preembedding immunogold cytochemistry in regions representative of those displaying prominent somatodendritic (bed nucleus of the stria terminalis and central nucleus of the amygdala) or merely diffuse (claustrum) labeling at the light microscopic level. In all of these regions, sst2A immunoreactivity was found to be associated exclusively with neurons. Neither glial nor endothelial vascular cells showed any significant immunogold labeling. Within neurons, $65 \%$ of the total number of gold particles was detected over dendrites. The remaining $35 \%$ was divided 

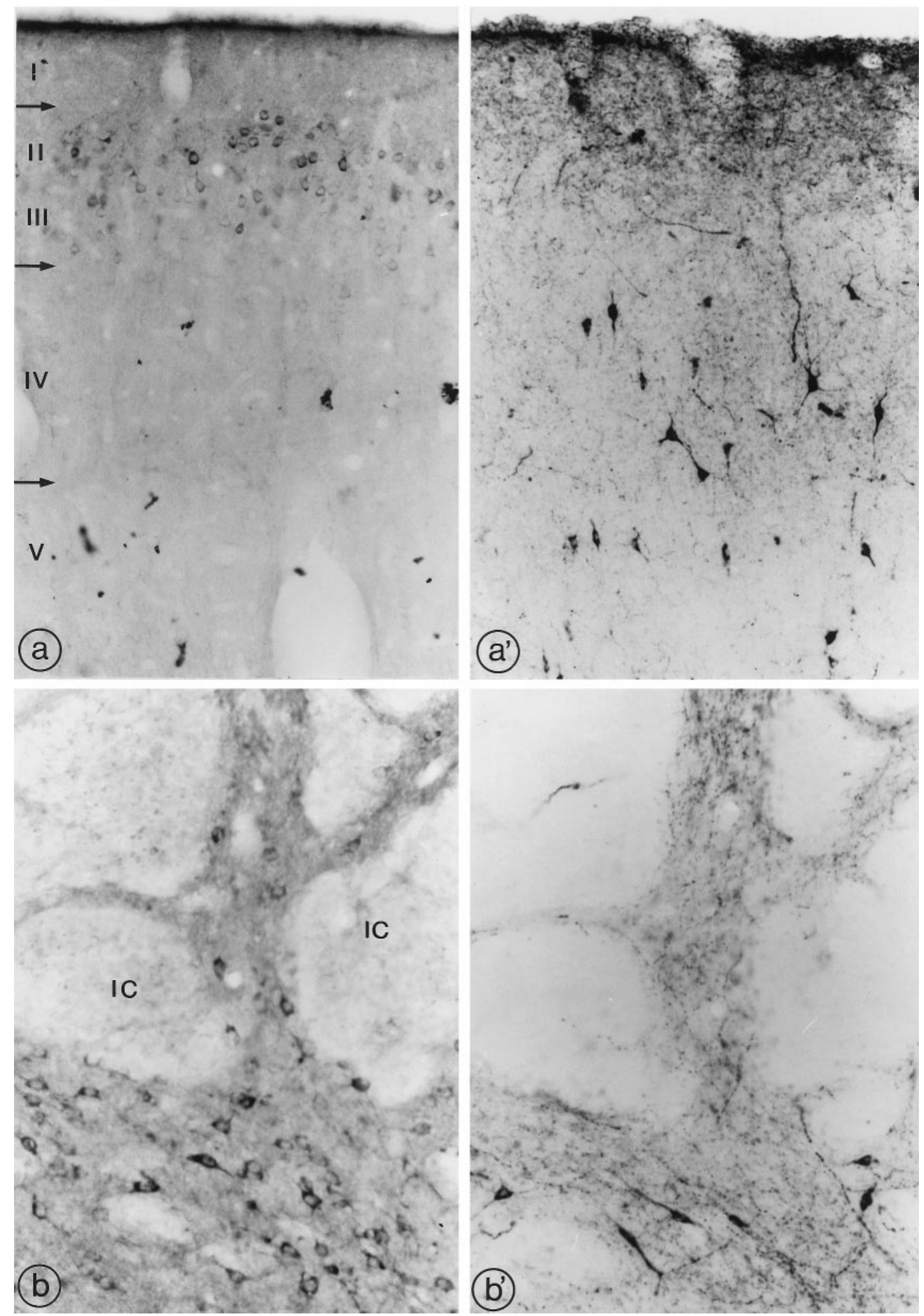

Figure 4. Distribution of sst2A receptor $(a, b)$ and SRIF immunoreactivity $\left(a^{\prime}, b^{\prime}\right)$ in the frontal cortex $\left(a, a^{\prime}\right)$ and the neostriatum $\left(b, b^{\prime}\right) . a, a^{\prime}$, Dense sst2A perikaryal labeling is evident throughout layers II-III of the frontal cortex $(a)$, whereas SRIF-immunoreactive positive cells are more sparse and predominate in layers IV and V $\left(a^{\prime}\right)$. Note the overlap between SRIF-immunoreactive processes and sst2A-immunoreactive nerve cell bodies in layers II-III. $b, b^{\prime}$, sst2A-immunoreactive neurons $(b)$ are detected among SRIF-immunoreactive perikarya and axons $\left(b^{\prime}\right)$ between the myelinated fascicles of the internal capsule $(I C)$ in the ventrolateral neostriatum. $a, a^{\prime}, 250 \times$ magnification; $b, b^{\prime}, 320 \times$ magnification. 

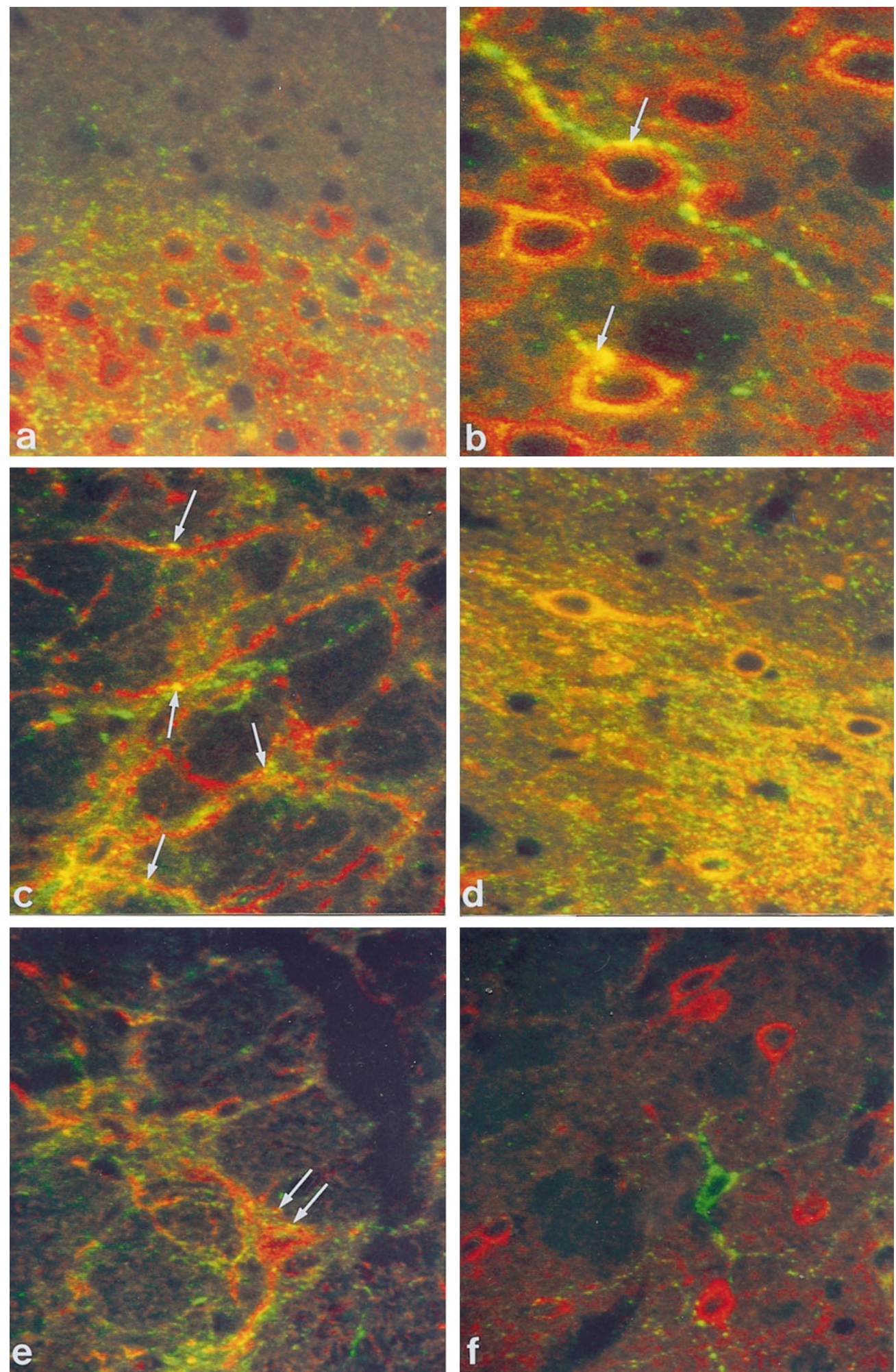

Figure 5. Confocal microscopic images of double sst2A receptor (red) and SRIF axonal ( green) immunolabeling in the olfactory tubercle (a), the central amygdaloid nucleus $(b)$, the spinal trigeminal tract $(c)$, the substriatal area $(d)$, the lateral reticular nucleus $(e)$, and the ventrolateral neostriatum $(f)$. In $a-e$, note the overlap between SRIF-immunoreactive axons and sst2A labeled perikarya and dendrites. In several instances, SRIF-immunoreactive varicosities are seen in close apposition with sst2A-stained elements $(a-c, e$; arrows). In the neostriatum $(f)$, a SRIF-immunoreactive soma is seen to extend immunoreactive processes toward several sst2A-immunoreactive neurons. $a, c-f, 600 \times$ magnification; $b, 2000 \times$ magnification. 

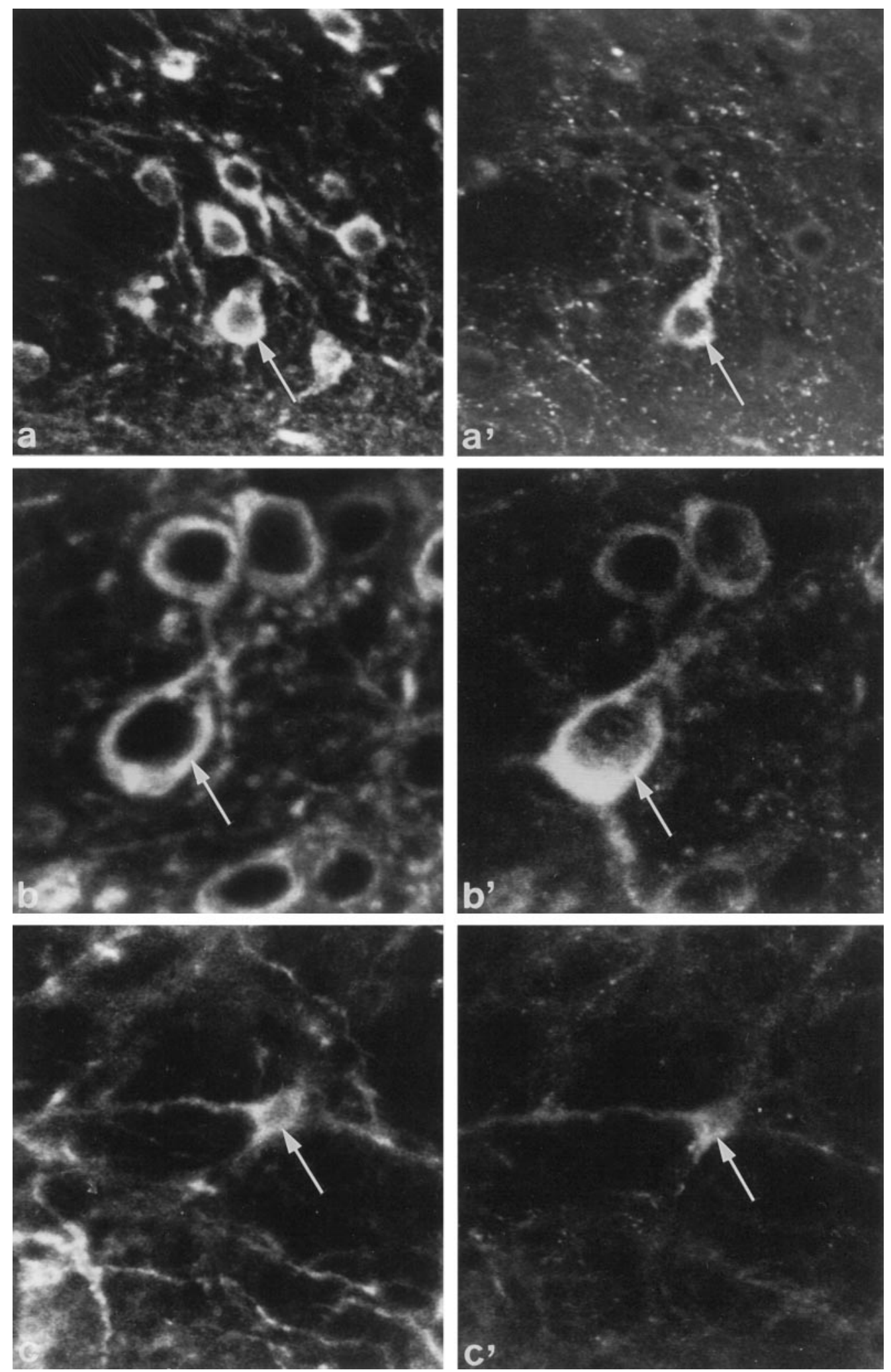

Figure 6. Confocal microscopic imaging of sst2A $(a-c)$ and SRIF $\left(a^{\prime}-c^{\prime}\right)$ double-labeled cells (arrows) in the central amygdaloid nucleus $\left(a, a^{\prime}\right)$, bed nucleus of the stria terminalis $\left(b, b^{\prime}\right)$, and lateral reticular nucleus $\left(c, c^{\prime}\right)$. Note that in all of these areas, SRIF immunoreactivity is detected only in a subpopulation of sst2A-expressing neurons. $a, a^{\prime}, c, c^{\prime}, 650 \times$ magnification; $b, b^{\prime}, 1200 \times$ magnification. 


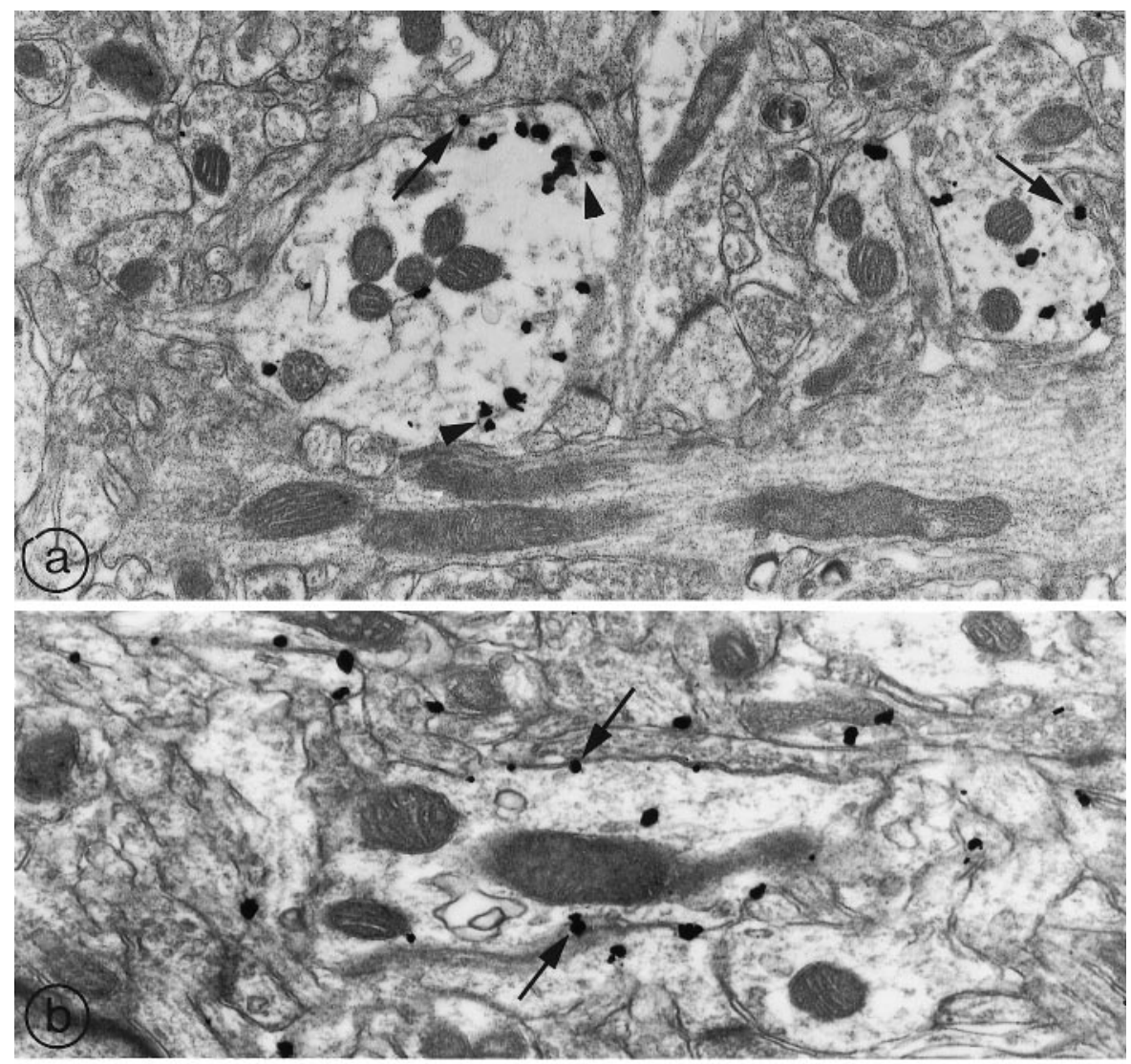

Figure 7. Electron microscopic localization of sst2A receptors using silver-enhanced immunogold in the central nucleus of the amygdala $(a)$ and claustrum $(b, c) . a$, A high proportion of gold particles is found inside dendrites, often in association with irregularly shaped vesicles (arrowheads). A few gold particles are also associated with the plasma membrane (arrows). $b, c$, Immunolabeled sst $2 \mathrm{~A}$ receptors are distributed mainly along dendritic plasma membranes (arrows). $a, b$, $28,000 \times$ magnification; $c, 20,000 \times$ magnification.

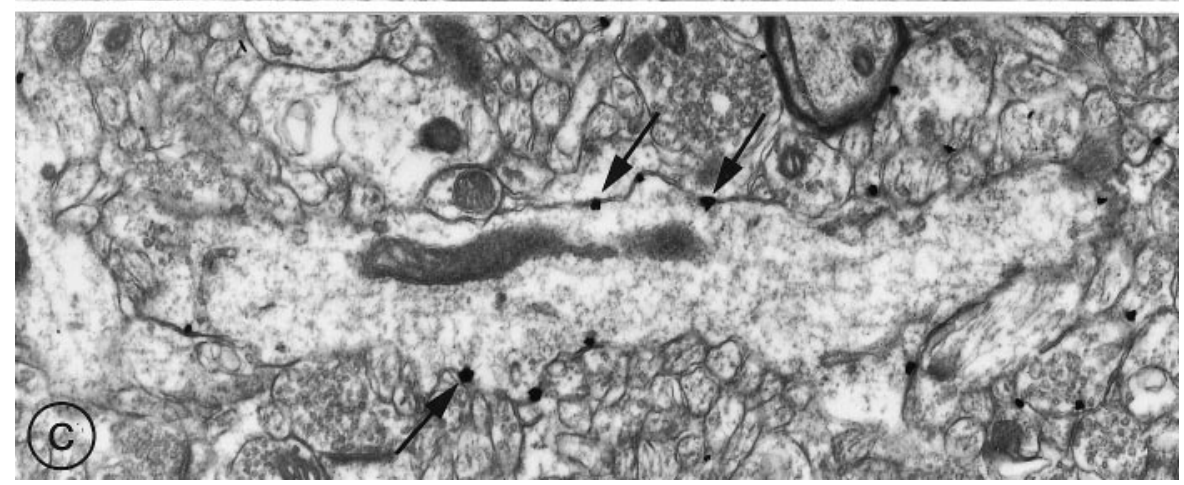

between soma, unmyelinated axons, and axon terminals, with variable enrichment according to the region sampled. Thus, in the bed nucleus of the stria terminalis and central nucleus of the amygdala, $26 \%$ of gold particles was associated with neuronal somata and $9 \%$ with unmyelinated axons and axon terminals. Conversely, in the claustrum, $11 \%$ of the immunolabeling was associated with somata and $24 \%$ with axons and axon terminals. However, the main difference between regions exhibiting somatodendritic (bed nucleus of the stria terminalis and central nucleus of the amygdala) as compared with diffuse (claustrum) labeling at the light microscopic level concerned the proportion of intracellular versus plasma membrane-associated sst $2 \mathrm{~A}$ receptors. In the former regions, only a small proportion of gold particles $(22 \%)$ was associated with the plasma membrane of nerve cell bodies, dendrites, or axons/axon terminals, the remainder being intracellular (Fig. 7a). By contrast, in the claustrum, $70 \%$ of labeled sst2A receptors was associated with the plasma membrane, and only $30 \%$ was intracellular (Fig. $7 b, c$ ). These differences could not be attributed to sampling, because the mean cross-sectional surface of labeled elements was comparable for all three areas.

Dual electron microscopic localization of sst2A receptors and SRIF was performed in two brain areas shown to exhibit significant overlap between immunoreactive SRIF fibers and sst2A receptor-expressing neurons at the light microscopic level, namely the bed nucleus of the stria terminalis and the central amygdaloid nucleus. In both of these regions, the peroxidase reaction product, indicative of SRIF immunoreactivity, was found almost exclusively in axon terminals. Only sparse immunoreactive dendrites were observed. SRIF-immunoreactive axon terminals measured $0.97 \pm 0.06 \mu \mathrm{m}$ in mean diameter and were filled with numerous clear synaptic vesicles. In addition, $50 \%$ of them also exhibited large dense core vesicles (one to three per terminal profile). Direct appositions between SRIF-immunoreactive terminals and sst2A-labeled somatodendritic elements were apparent on $23 \%$ (39 of 168) and 10\% (8 of 69) of labeled terminal profiles sampled in the bed nucleus of the stria terminalis and central amygdaloid nucleus, respectively (Fig. 8). Contacted elements were predom- 

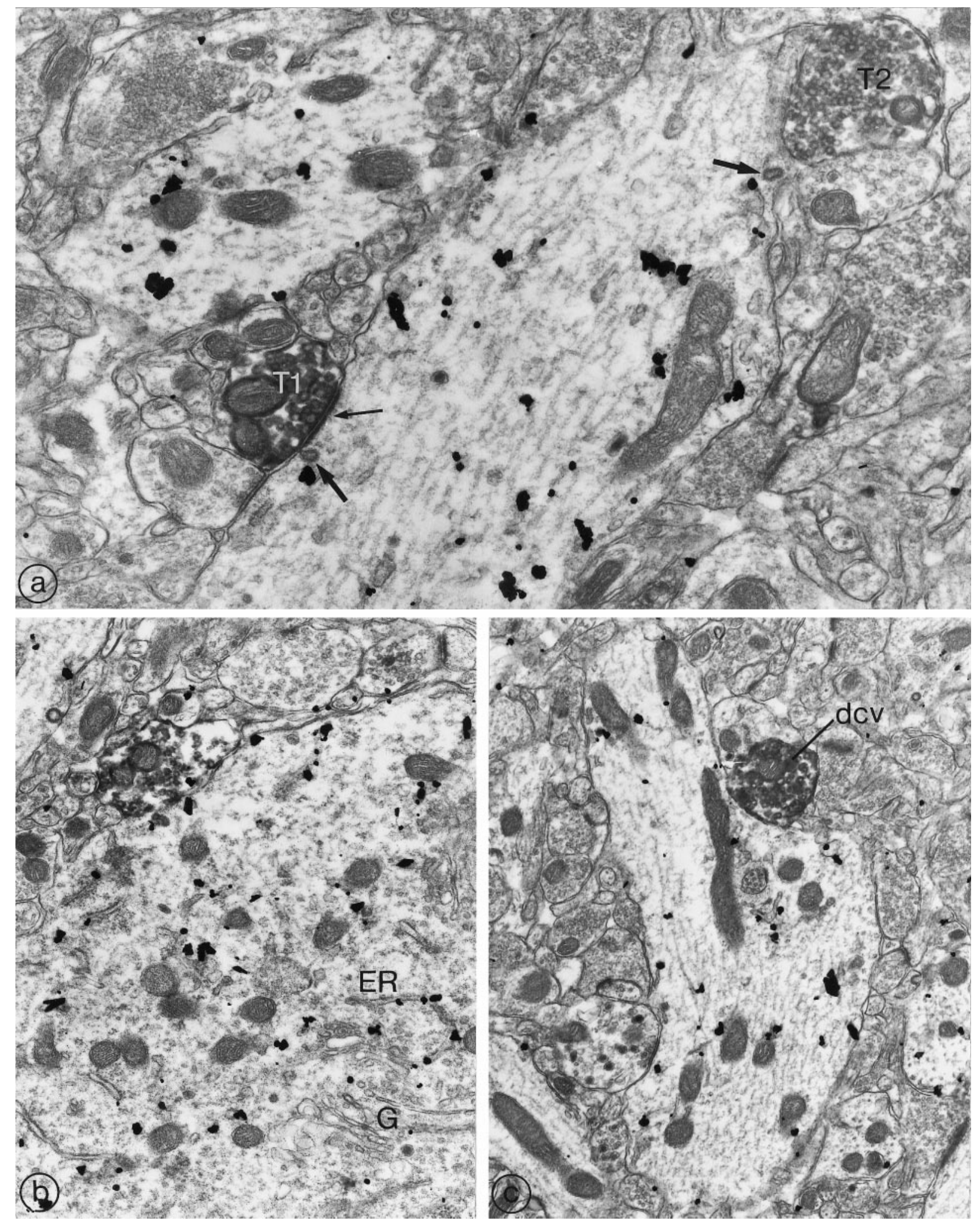

Figure 8. Combined visualization of sst2A receptors and SRIF-containing axons in the central nucleus of the amygdala using immunogold and immunoperoxidase labeling, respectively. $a$, sst2A-immunoreactive dendritic trunk contacted by two SRIF-immunoreactive terminals (T1, $T 2)$. $T 1$ is more strongly immunoreactive than $T 2$ and shows an asymmetric specialization at the site of contact (small arrow). Note that most of the gold particles are intracellular and that many of them are associated with vesicular elements. Also note the presence of coated "endocytic" vesicles on the postsynaptic side, close to the sites of contact (large arrows). b, sst2A-immunopositive cell body in contact with a SRIF-immunoreactive terminal. Here again, most of the gold particles are intracellular. Some of them are associated with organelles implicated in protein synthesis and maturation such as the Golgi apparatus $(G)$ and endoplasmic reticulum $(E R)$. Two of the gold particles are seen in the vicinity of the abutting SRIF terminal. $c$, An intensely labeled SRIF terminal containing several dense core vesicles $(d c v)$ is seen in symmetric synaptic contact with a large sst2A-immunoreactive dendrite displaying prominent intracellular labeling. Again, note that only a few gold particles are associated with the plasma membrane. $a, 28,000 \times$ magnification; $b, c, 17,000 \times$ magnification. 
inantly large dendrites and, less frequently, dendritic branchlets and perikarya (Fig. 8). The proportion of membrane-associated versus intracellular sst $2 \mathrm{~A}$ receptors within these dendrites was similar to that observed in dendrites lacking any apparent contact with SRIF elements. Membrane-associated sst2A receptors expressed in dendrites apposed to SRIF-containing terminals were distributed on the entire surface of the dendrites and not specifically opposite the abutting SRIF terminal. Nonetheless, $29 \%$ of appositions between the two types of immunolabeled elements showed a gold particle at the site of apposition. Of the SRIF terminals contacting sst $2 \mathrm{~A}$ somatodendritic elements, only $20 \%$ exhibited a synaptic specialization in the plane of section. These synapses were mainly symmetrical (Fig. $8 c$ ), but a few showed a high postsynaptic differentiation typical of asymmetric synapses (Fig. 8a). Occasionally, SRIF-immunoreactive terminals apposed or not to sst2A-positive dendrites established synaptic junctions with nonlabeled neuronal elements.

\section{DISCUSSION}

The present study provides a comprehensive description of the regional and cellular relationships between SRIF axons and SRIF receptor-expressing neurons in the CNS. Although the SRIF receptor subtype visualized here, sst $2 \mathrm{~A}$, represents only one of the six SRIF receptors (including the sst2B receptor variant) cloned to date (Bruno et al., 1992; O'Carroll et al., 1992; Vanetti et al., 1992; Yamada et al., 1992; Yasuda et al., 1992), pharmacological (Reisine and Bell, 1995), and neuroanatomical (Martin et al., 1991; Pérez et al., 1994; Senaris et al., 1994; Beaudet et al., 1995; Schoeffter et al., 1995; Holloway et al., 1996) data suggest that it accounts for an important facet of somatostatinergic neurotransmission in the brain.

The immunohistochemical methods used in the present investigation relied on the use of well characterized SRIF and sst2A receptor antibodies (Dun et al., 1994; Dournaud et al., 1996; Gu and Schonbrunn, 1997). Further support for the specificity of SRIF and sst2A immunolabeling patterns observed here stemmed from their similarity with those obtained in previous studies using either the same (Dun et al., 1994; Dournaud et al., 1996) or different (Johannson et al., 1984; Schindler et al., 1997) antibodies.

As reported previously (Dournaud et al., 1996), two types of sst2A immunostaining patterns were observed by light microscopy in serial sections from the rat brain. In some regions, such as the bed nucleus of the stria terminalis, the olfactory tubercle, the central amygdaloid nucleus, or the nucleus accumbens, the immunostaining was clearly associated with neuronal perikarya and dendrites. In others, such as in the endopiriform nucleus, the claustrum, the basal lateral amygdaloid nucleus, or layers V-VI of the cerebral cortex, the immunostaining appeared diff usely distributed in tissue. Electron microscopic immunogold cytochemistry gave the key to these discrepant light microscopic labeling patterns. Indeed, in regions of somatodendritic sst2A labeling, most immunoreactive receptors were intracellular and only a small proportion were associated with plasma membranes, whereas in regions of diff use sst2A labeling, the vast majority of immunoreactive receptors was associated with neuronal plasma membranes. A second major finding of the present study was that the density of SRIF-immunoreactive axon terminals varied according to the above compartmentalization such that regions in which sst2A receptors were predominantly intracellular contained high densities of SRIF axon terminals, whereas regions in which sst $2 \mathrm{~A}$ receptors were predominantly membrane-bound received only a sparse SRIF innervation.

The fact that regions in which sst2A receptors were mainly intracellular contained a dense SRIF innervation suggests that endogenously released SRIF may chronically downregulate membrane-associated receptors. In light of recent studies in which pharmacological stimulation of neuropeptide receptors was shown to result in their translocation from the cell surface to the cytoplasm (Liu et al., 1997), it is tempting to speculate that this downregulation is a consequence of ligand-induced receptor internalization. Such a mechanism has been described for various neuropeptide receptors in the CNS, including opioid (Sternini et al., 1996), substance P (Mantyh et al., 1995a,b), and neurotensin (Faure et al., 1995) receptors. The sst2A receptor has been shown to efficiently internalize bound ligand when expressed in COS-7 cells (Nouel et al., 1997), human embryonic kidney (HEK) cells (Roth et al., 1997), $\mathrm{GH}_{4}$-R2.20 pituitary tumor cells (Hipkin et al., 1997), and to a much lesser extent, Chinese hamster ovary cells (Hukovic et al., 1996). Furthermore, bound SRIF receptor ligands recently have been demonstrated to be internalized in neurons in primary cultures (Stroh et al., 1997) as well as in Neuro2A neuroblastoma cells (Koening et al., 1997), both of which express the sst 2 receptor subtype. These studies indicate that internalization of the somatostatin-sst $2 \mathrm{~A}$ receptor complex is dependent on receptor occupancy and could account for a paucity of cell surface receptors in regions where there is substantial endogenous SRIF release.

In turn, the fact that regions in which sst $2 \mathrm{~A}$ receptors were mainly associated with the plasma membranes received only a sparse SRIF innervation implies that in these regions the endogenous ligand must diffuse over some distance in the extracellular space to reach its receptor targets. Such a mode of action has been postulated previously for a number of neuropeptides in the CNS (for review, see Herkenham, 1987) and was documented in vivo for substance P (Mantyh et al., 1995a,b). The present results suggest further that within these regions the concentration of endogenous SRIF that reaches its receptor targets may not be sufficient to induce a cell surface receptor downregulation as extensive as in regions of dense SRIF innervation.

In regions of membrane-associated sst $2 \mathrm{~A}$ immunolabeling, the distribution of sst2A-immunoreactive receptors was highly correlated with that previously reported for SRIF binding sites autoradiographically labeled with sst2-preferring ligands. By contrast, the two distributions did not correlate in regions of predominantly intracellular somatodendritic labeling. Admittedly, these correlations may be confounded somewhat by the fact that all current sst2-preferring ligands also recognize, to some extent, sst3 and sst5 subtypes (Raynor et al., 1993; Epelbaum et al., 1994). However, it would appear from recent literature reports that the recombinant sst 2 receptor is the one that is preferentially labeled by autoradiography when using sst2-preferring ligands (Schoeffter et al., 1995; Holloway et al., 1996). The most likely interpretation for these correlative data is that sst2-preferring ligands bind mainly to membrane-associated, as opposed to intracellular, receptors. Why intracellular sst2A receptors, in contrast to other types of neuropeptide receptors such as neurotensin (Kessler et al., 1987, Dana et al., 1989; Szigethy et al., 1990) or $\delta$ opioid (Pasquini et al., 1992) receptors, should poorly recognize their exogenous ligand is unclear but may be related to the conformation of neosynthesized receptors or to chemical alteration (e.g., phosphorylation) (Hipkin et al., 1997) of internalized ones. It could also be caused by their inclusion in small 
membrane-bound compartments (such as endosomes) where they might be unaccessible to, or already occupied by, the ligand. In any event, the fact that in regions of "somatodendritic" light microscopic sst2A labeling immunoreactive receptors were found by electron microscopy to be predominantly intracellular provides an explanation for the "mismatch" between ${ }^{125}$ I-SRIF binding and SRIF immunoreactivity reported previously in these areas (Herkenham, 1987).

Not all brain regions showed a correlation between densities of SRIF terminals and somatodendritic sst2A receptor labeling. Thus, in the hypothalamus, a dense SRIF innervation was detected in the absence of any substantial somatodendritic or diff use sst2A receptor immunoreactivity. Because this region is also largely deprived of sst 2 binding activity (Reubi and Maurer, 1985; Krantic et al., 1989, 1990; Martin et al., 1991; Schoeffter et al., 1995; Holloway et al., 1996), the most likely interpretation for the observed mismatch is the presence of one or several additional SRIF receptor subtypes, a proposal supported by in situ hybridization data (Breder et al., 1992; Senaris et al., 1994; Beaudet et al., 1995; Pérez and Hoyer, 1995). Other regions, such as the medial habenula, locus coeruleus, and pyramidal cell layer of the CA1-CA2 hippocampal fields showed dense sst2A somatodendritic immunoreactivity but only a sparse SRIF innervation. Two of these areas, namely the medial habenula and the locus coeruleus, also showed high sst2 binding activity. It remains to be confirmed by electron microscopy whether a high incidence of membrane-associated receptors exists in these regions in contrast to other areas of sst2A somatodendritic labeling. These findings would show whether factors other than ligand exposure could also be involved in the regulation of cell surface receptor density.

Confocal microscopic examination of doubled-labeled material revealed that SRIF and sst $2 \mathrm{~A}$ receptors were colocalized within the same neurons in several brain regions, including the bed nucleus of the stria terminalis, the central amygdaloid nucleus, and the premammillary nucleus. These observations suggest that SRIF may be in a position to regulate the activity of SRIF neurons, and presumably its own release, in several brain structures. Because our experiments were conducted in noncolchicinetreated rats (to optimize visualization of axon terminals), it is likely that colocalization of sst $2 \mathrm{~A}$ receptors and SRIF is more pervasive than our results and than earlier functional studies (Peterfreund and Vale, 1984; Epelbaum et al., 1986; Richardson and Twente, 1986) had led us to believe.

Electron microscopy demonstrated the existence of direct appositions between SRIF-immunoreactive axons and sst2Aimmunoreactive neurons in the bed nucleus of the stria terminalis and the central nucleus of the amygdala. Although the incidence with which SRIF terminal profiles were seen in contact with sst2A-immunoreactive elements in single thin sections was relatively low, a simple stereological calculation (based on the assumption that these terminals are spherical and taking into account their diameter and length of contact with the sst2A element) (for mathematical formula, see Beaudet and Sotelo, 1981) reveals that in the bed nucleus of the stria terminalis up to $37 \%$ of the SRIF-immunoreactive terminals are actually in contact with sst2A-immunoreactive perikarya and dendrites. Furthermore, this figure is likely to be even higher if, as likely, all sst2A-positive dendrites do not exhibit silver-gold particles in the plane of sections in which they are contacted by SRIF terminals. The present data therefore indicate that in regions of dense SRIF innervation-low cell surface sst2A receptor expression, there is an extensive investment of sst $2 \mathrm{~A}$ receptor-expressing elements by
SRIF axon terminals. Surprisingly, however, only $20 \%$ of these terminals showed a synaptic specialization at the site of contact. Furthermore, labeled receptors were observed only rarely at these sites of contact, whether or not a synaptic specialization was present. These observations suggest that SRIF may not be the "synaptic" transmitter released by these terminals, but a cotransmitter acting more broadly on receptors located on extrasynaptic portions of the membrane. Nonetheless, the present results suggest that direct contact between SRIF-containing axons and receptive neurons may be critical for a fast, efficient action of SRIF on sst $2 A$ receptors. Whether SRIF released from terminals located at a distance from sst2A-expressing elements acts on the same receptors, through diffusion in the extracellular space, or on other types of SRIF receptors present on sst2A-immunonegative elements remains to be determined.

In summary, the major conclusions drawn from our observations are the following. (1) Regions in which sst2A receptors are mainly intracellular receive a dense SRIF innervation, suggesting that endogenously released SRIF chronically downregulates membrane-associated receptors; (2) regions in which sst2A receptors are predominantly membrane-associated receive only a sparse SRIF innervation, implying that the exogenous ligand must diffuse over some distance in the extracellular space to reach its targets; and (3) regions in which sst2A-immunoreactive receptors are associated predominantly with plasma membranes correspond to regions shown previously by quantitative autoradiography to be most enriched in sst2 binding sites, implying (1) that intracellular sst $2 \mathrm{~A}$ receptors are ill-recognized by exogenous SRIF and (2) that these regions are preferential targets for exogenously administered SRIF or its derivatives.

\section{REFERENCES}

Beaudet A, Sotelo C (1981) Synaptic remodeling of serotonin axon terminals in rat agranular cerebellum. Brain Res 206:305-329.

Beaudet A, Greenspun D, Raelson J, Tannenbaum GS (1995) Patterns of expression of SSTR1 and SSTR2 somatostatin receptor subtypes in the hypothalamus of the adult rat: relationship to neuroendocrine function. Neuroscience 65:551-561.

Brazeau P, Vale W, Burgus R, Ling N, Butcher M, Rivier J, Guillemin R (1973) Hypothalamic polypeptide that inhibits the secretion of immunoreactive pituitary growth hormone. Science 179:77-78.

Breder CD, Yamada Y, Yasuda K, Seino K, Saper CB, Bell GI (1992) Differential expression of somatostatin receptor subtypes in brain. J Neurosci 12:3920-3934.

Bruno JF, Xu Y, Song J, Berelowitz M (1992) Molecular cloning and functional expression of a brain-specific somatostatin receptor. Proc Natl Acad Sci USA 89:11151-11155.

Chan J, Aoki C, Pickel VM (1990) Optimization of differential immunogold-silver and peroxidase labeling with maintenance of ultrastructure in brain sections before plastic embedding. J Neurosci Methods 33:113-127.

Dana C, Vial M, Leonard K, Beauregard A, Kitabgi P, Vincent JP, Rostène W, Beaudet A (1989) Electron microscopic localization of neurotensin binding sites in the midbrain tegmentum of the rat. J Neurosci 9:2247-2257.

De Lecea L, Criado JR, Prospero-Garcia O, Gautvik KM, Schweitzer P, Danielson PE, Dunlop CLM, Siggins GR, Henriksen SJ, Sutcliffe JG (1996) A cortical neuropeptide with neuronal depressant and sleepmodulating properties. Nature 381:242-245.

Dournaud P, Gu YZ, Schonbrunn A, Mazella J, Tannenbaum GS, Beaudet A (1996) Localization of the somatostatin receptor sst2A in rat brain using a specific anti-peptide antibody. J Neurosci 16:4468-4478.

Dun NJ, Dun SL, Wong RKS, Förstremann U (1994) Colocalization of nitric oxide synthase and somatostatin immunoreactivity in rat dentate hilar neurons. Proc Natl Acad Sci USA 91:2955-2959.

Epelbaum J, Tapia-Arancibia L, Alonso G, Astier H, Kordon C (1986) The anterior periventricular hypothalamus is the site of somatostatin inhibition on its own release: an in vitro and immunocytochemical study. Neuroendocrinology 44:255-259. 
Epelbaum J, Dournaud P, Fodor F, Viollet C (1994) The neurobiology of somatostatin. Crit Rev Neurobiol 8:25-44.

Faure MP, Alonso A, Nouel D, Gaudriault G, Dennis M, Vincent JP, Beaudet A (1995) Somatodendritic internalization and perinuclear targeting of neurotensin in mammalian brain. J Neurosci 15:4140-4147.

Fukusumi S, Kitada C, Takekawa S, Kizawa H, Sakamoto J, Miyamoto M, Hinuma S, Kitano K, Fujino M (1997) Identification and characterization of a novel human cortistatin-like peptide. Biochem Biophys Res Commun 232:157-163.

Gu WZ, Schonbrunn A (1997) Coupling specificity between somatostatin receptor sst2A and $\mathrm{G}$ proteins: isolation of the receptor$\mathrm{G}$ protein complex with a receptor antibody. Mol Endocrinol 11:527-537.

Gu WZ, Brown PJ, Loose-Mitchell DS, Stork PJS, Schonbrunn A (1995) Development and use of a receptor antibody to characterize the interaction between somatostatin subtype 1 and $\mathrm{G}$ proteins. Mol Pharmacol 48:1004-1014.

Herkenham M (1987) Mismatches between neurotransmitter and receptor localizations in brain: observations and implications. Neuroscience 23:1-38.

Hipkin RW, Friedman J, Clark RB, Eppler CM, Schonbrunn A (1997) Agonist-induced desensitization, internalization, and phosphorylation of the sst2A somatostatin receptor. J Biol Chem 272:13869-13876.

Holloway S, Feniuk W, Kidd EJ, Humphrey PPA (1996) A quantitative autoradiographical study on the distribution of somatostatin sst2 receptors in the rat central nervous system using ${ }^{125}$ I-BIM-23027. Neuropharmacology 35:1109-1120.

Hoyer D, Bell GI, Berelowitz M, Epelbaum J, Feniuk W, Humphrey PP, O'Caroll AM, Patel YC, Schonbrunn A, Taylor JE, Reisine T (1995) Classification and nomenclature of somatostatin receptors. Trends Pharmacol Sci 16:86-88.

Hukovic N, Panetta R, Kumar U, Patel YC (1996) Agonist-dependent regulation of cloned human somatostatin receptor types 1-5 (hSSTR15): subtype selective internalization or upregulation. Endocrinology 137:4046-4049.

Johannson O, Hökfelt T, Elde PR (1984) Immunohistochemical distribution of somatostatin-like immunoreactivity in the central nervous system of the adult rat. Neuroscience 13:265-339.

Kessler JP, Moyse E, Kitabgi P, Vincent JP, Beaudet A (1987) Distribution of neurotensin binding sites in the caudal brainstem of the rat: a light microscopic radioautographic study. Neuroscience 23:189-198.

Koening JA, Edwardson JM, Humphrey PPA (1997) Somatostatin receptors in Neuro2A neuroblastoma cells: ligand internalization. $\mathrm{Br} \mathrm{J}$ Pharmacol 120:52-59.

Krantic S, Martel JC, Weissmann D, Quirion R (1989) Radioautographic analysis of somatostatin receptor sub-type in rat hypothalamus. Brain Res 498:267-278.

Krantic S, Martel JC, Weissmann D, Pujol JF, Quirion R (1990) Quantitative radioautographic study of somatostatin receptors heterogeneity in the rat extrahypothalamic brain. Neuroscience 39:127-137.

Krantic S, Quirion R, Uhl G (1992) Somatostatin receptors. In: Handbook of chemical neuroanatomy, Vol II, Neuropeptide receptors in the CNS (Björklund A, Hökfelt T, Kuhar MJ, eds), pp 321-346. Amsterdam: Elsevier Science.

Liu H, Mantyh PW, Basbaum AI (1997) NMDA-receptor regulation of substance $\mathrm{P}$ release from primary afferent nociceptors. Nature 368:721-724.

Mantyh PW, Allen CJ, Ghilardi JR, Rogers SD, Mantyh CR, Liu H, Basbaum AI, Vigna SR, Maggio JE (1995a) Rapid endocytosis of a G protein-coupled receptor: substance-P evoked internalization of its receptor in the rat striatum in vivo. Proc Natl Acad Sci USA 92:2622-2626.

Mantyh PW, De Master E, Malhorta A, Ghilardi JR, Rogers SD, Mantyh CR, Liu H, Basbaum AI, Vigna SR, Maggio JE, Simone DA (1995b) Receptor endocytosis and dendrite reshaping in pineal neurons after somatosensory stimulation. Science 268:1629-1632.

Martin JL, Chesselet MF, Raynor K, Gonzales C, Reisine T (1991) Differential distribution of somatostatin receptor subtypes in rat brain revealed by newly developed somatostatin analogs. Neuroscience 41:581-593.

Moyse E, Beaudet A, Bertherat J, Epelbaum J (1992) Light microscopic radioautographic localization of somatostatin binding sites in the brainstem of the rat. J Chem Neuroanat 5:75-84.

Nouel D, Gaudriault G, Houle M, Reisine T, Vincent JP, Mazella J, Beaudet A (1997) Differential internalization of somatostatin in COS-7 cells transfected with SST1 and SST2 receptor subtypes: a confocal microscopic study using novel fluorescent somatostatin derivates. Endocrinology 138:296-306.

O'Carroll AM, Lolait SJ, Konig M, Mahan LC (1992) Molecular cloning and expression of a pituitary somatostatin receptor with preferential affinity for somatostatin-28. Mol Pharmacol 42:939-946.

Pasquini F, Bochet P, Garbay-Jaureguiberry C, Roques BP, Rossier J, Beaudet A (1992) Electron microscopic localization of photoaffinitylabelled delta opioid receptors in the neostriatum of the rat. J Comp Neurol 326:229-244.

Patel YC, Greenwood MT, Panetta R, Demchyshyn L, Niznik H, Srikant CB (1995) The somatostatin receptor family. Life Sci 57:1249-1265.

Pérez J, Hoyer D (1995) Co-expression of somatostatin sstr-3 and sstr-4 receptor messenger RNAs in the rat brain. Neuroscience 64:241-253.

Pérez J, Rigo M, Kaupmann K, Bruns C, Yasuda K, Bell GI, Lubbert H, Hoyer D (1994) Localization of somatostatin (SRIF) SSTR-1, SSTR-2 and SSTR-3 receptor mRNA in rat brain by in situ hybridisation. Naunyn Schmiedebergs Arch Pharmacol 349:145-160.

Peterfreund RA, Vale WW (1984) Somatostatin analogs inhibit somatostatin secretion from cultured hypothalamus cells. Neuroendocrinology 39:397-402.

Pradayrol L, Jornvall H, Mutt V, Ribet A (1980) N-terminally extended somatostatin 28. FEBS Lett 109:55-58.

Raynor K, Murphy WA, Coy DH, Taylor JE, Moreau J-P, Yasuda K, Bell GI, Reisine T (1993) Cloned somatostatin receptors: identification of subtype-selective peptides and demonstration of high affinity binding of linear peptides. Mol Pharmacol 43:838-844.

Reichlin S (1983) Somatostatin. N Engl J Med 309:1556-1563.

Reisine T, Bell GI (1995) Molecular properties of somatostatin receptors. Neuroscience 67:777-790.

Reubi JC, Maurer R (1985) Autoradiographic mapping of somatostatin receptors in the rat central nervous system and pituitary. Neuroscience 15:1183-1193.

Richardson SB, Twente S (1986) Inhibition of rat hypothalamus somatostatin release by somatostatin: evidence for ultrashort loop feedback. Endocrinology 118:2076-2082.

Roth A, Kreienkamp H-J, Nehring RB, Roosterman D, Meyerhof W, Richter D (1997) Endocytosis of the rat somatostatin receptors: subtype discrimination, ligand specificity, and delineation of carboxyterminal positive and negative sequence motifs. DNA Cell Biol 16:111-119.

Sawchenko PE, Benoit R, Brown MR (1988) Somatostatin 28immunoreactive neurons inputs to the paraventricular and supraoptic nuclei: principal origin from nonaminergic neurons in the nucleus of the solitary tract. J Chem Neuroanat 1:81-94.

Schally AV, Huang WY, Chang RLL, Arimura A, Redding TW, Millar RP, Hunkapillar MW, Hood LE (1980) Isolation and structure of pro-somatostatin precursor from pig hypothalamus. Proc Natl Acad Sci USA 77:4489-4493.

Schindler M, Humphrey PP, Emson PC (1996) Somatostatin receptors in the central nervous system. Prog Neurobiol 50:9-47.

Schindler M, Sellers LA, Humphrey PPA, Emson PC (1997) Immunohistochemical localization of the somatostatin SST2A receptor in rat brain and spinal cord. Neuroscience 76:225-240.

Schoeffter P, Pérez J, Langenegger D, Schupbach E, Bobirnac I, Lubbert H, Bruns C, Hoyer D (1995) Characterization and distribution of somatostatin SS-1 and SRIF-1 binding sites in rat brain: identity with SSTR-2 receptors. Eur J Pharmacol 289:163-173.

Schwarzer C, Sperk G, Samanin R, Rizzi M, Gariboldi M, Vezzani A (1996) Neuropeptides-immunoreactivity and their mRNA expression in kindling: functional implications for limbic epileptogenesis. Brain Res Brain Res Rev 22:27-50.

Senaris RM, Humphrey PPA, Emson PC (1994) Distribution of somatostatin receptors 1,2 and 3 mRNA in rat brain and pituitary. Eur J Neurosci 6:1883-1896.

Sternini C, Spann M, Anton B, Keith Jr DE, Bunnett NW, Von Zastrow M, Evans C, Breacha NC (1996) Agonist-selective endocytosis of mu opioid receptor by neurons in vivo. Proc Natl Acad Sci USA 93:9241-9246. 
Stroh T, Schonbrunn A, Vincent JP, Beaudet A (1997) The somatostatin receptor sst2A in primary cortical cultures: expression and internalization. In: Göttingen neurobiology report, Proceedings of the 25th Göttingen neurobiology conference, Vol II (Elsner N, Wässle H, eds), pp 791. Stuttgart: Georg Thieme Verlag.

Szigethy E, Leonard K, Beaudet A (1990) Ultrastructural localization of $\left[{ }^{125} \mathrm{I}\right]$-neurotensin binding sites to cholinergic neurons of the rat nucleus basalis magnocellularis. Neuroscience 36:377-391.

Tannenbaum GS (1985) Physiological role of somatostatin in regulation of pulsatile growth hormone secretion. In: Somatostatin (Patel YC, Tannenbaum GS, eds), pp 229-259. New York: Plenum.

Vanetti M, Kouba M, Wang X, Vogt G, Hollt V (1992) Cloning and expression of a novel mouse somatostatin receptor (SSTR2B). FEBS Lett 311:290-294.

Vanetti M, Vogt G, Hollt V (1993) The two isoforms of the mouse somatostatin receptor (mSSTR2A and mSSTR2B) differ in coupling efficiency to adenylate cyclase and in agonist-induced receptor desensitization. FEBS Lett 331:260-266.

Yamada Y, Post SR, Wang K, Tager HS, Bell GI, Seino S (1992) Cloning and functional characterization of a family of human and mouse somatostatin receptors expressed in brain, gastrointestinal tract, and kidney. Proc Natl Acad Sci USA 89:251-255.

Yasuda K, Rens-Domiano S, Breder CD, Law SF, Saper CB, Reisine T, Bell GI (1992) Cloning of a novel somatostatin receptor, SSTR3, coupled to adenylylcyclase. J Biol Chem 267:20422-20428. 